\title{
Isolated Left Trochlear Nerve Palsy Caused by Sphenoid Sinus Mucocele
}

\author{
Philip Lee, Jae Sang Han, Young Ha Kim, and So Young Park \\ Department of Otorhinolaryngoloy-Head and Neck Surgery, College of Medicine, The Catholic University of Korea, Seoul, Korea
}

\author{
접형동 점액낭종으로 인한 좌측 활차신경 단독 마비 \\ 이필립 · 한재상 · 김영하 · 박소영 \\ 가톨릭대학교 의과대학 이비인후-두경부외과학교실
}

\author{
Received August 11, 2016 \\ Revised September 16, 2016 \\ Accepted October 12, 2016 \\ Address for correspondence \\ So Young Park, MD, PhD \\ Department of Otorhinolaryngology- \\ Head and Neck Surgery, \\ Yeouido St. Mary's Hospital, \\ College of Medicine, \\ The Catholic University of Korea, \\ 10 63-ro, Yeongdeungpo-gu, \\ Seoul 07345, Korea \\ Tel $+82-2-3779-1044$ \\ Fax +82-2-786-1149 \\ E-mailsypak@catholic.ac.kr
}

Paranasal sinus mucoceles are an uncommon cause of isolated palsies of cranial nerves III, IV, and VI. The trochlear nerve has been reported to be less frequently affected than the abducens and oculomotor nerves. Isolated sphenoid sinus diseases may cause serious complications by involving adjacent vital structures such as the optic nerve, cavernous sinus, internal carotid artery, and cranial nerves III-VI. We report a case of a 76-year-old woman who presented to our emergency department with a chief complaint of acute double vision and headache. Her diplopia was diagnosed as left trochlear nerve palsy. Brain CT and MRI revealed expanding cystic lesions in both sphenoid sinuses with bony erosion of the left sinus wall. The patient underwent an endoscopic intranasal sphenoidotomy and recovered completely from diplopia at postoperative 2 months. The relationship between the trochlear nerve palsy and its anatomy is also discussed. Korean J Otorhinolaryngol-Head Neck Surg 2017;60(10):531-4

Key Words Diplopia $\cdot$ Forth cranial nerve $\cdot$ Paranasal sinus $\cdot$ Superior oblique muscle Superior orbital fissure.

\section{서 론}

외안근마비는 복시와 시력장애를 일으키는 질환으로 뇌신 경 $3,4,6$ 번 마비에 의해 주로 발생한다. 단독 마비는 대부분 3 번과 6번이고 4번은 드물며 복합 마비는 3번과 6번, 또는 세 신경 모두의 조합이 많다. 급성 마비의 주된 원인으로 동안 신경은 혈관병 및 동맥류, 외전신경은 다발성경화증이나 수 막뇌염 같은 염증성 질환, 그리고 활차신경은 머리 외상에 의 해 가장 많이 발생한다고 보고되었다. ${ }^{1)}$ Mollan 등르는 성인의 상사근(superior oblique muscle) 마비 원인을 선천성, 외상, 혈관병의 순으로 보고하였다. 비외상성 후천성 활차신경마비 는 당뇨, 고혈압, 고콜레스테롤혈증 등이 동반될 때 미세혈관

This is an Open Access article distributed under the terms of the Creative Commons Attribution Non-Commercial License (http://creativecommons.org/licenses/by-nc/4.0) which permits unrestricted non-commercial use, distribution, and reproduction in any medium, provided the original work is properly cited.
성으로 분류되고, 혈관위험인자가 없을 때 특발성으로 분류 되는데 이들은 뇌영상에서 두개 내 병변이 발견되지 않고 보 통 수주에서 수개월 내에 자연 회복되는 경우가 많은 것이 특 징이다. ${ }^{2,3)}$ 그러나, 뇌신경 $3,4,6$ 번 마비와 연관된 부비동질 환은 매우 드물어 원인의 한 범주를 차지하고 있지 않다. 접형 동의 단독 병변은 모든 부비동 병변 중에서 $3 \%$ 이내로 알려 져 있고 가장 흔한 원인 인자는 염증성 병변으로 10 17\%를 점액낭종이 차지한다. ${ }^{4)}$ 부비동 점액낭종은 부비동 내에 점액 이 저류되는 확장성 낭종성 병변으로, 특히 접형동은 시신 경, 해면정맥동, 내경동맥, 그리고 $3,4,6$ 번 뇌신경 등과 인접 해 있어 팽창하는 낭종이 이들 중요 구조물과의 경계가 되는 얇은 골판을 쉽게 침범하여 임상 증상을 일으키게 된다. ${ }^{5}$ 그 러므로 접형동 점액낭종은 양성 질환이지만 시신경관(optic canal)이나 상안와열(superior orbital fissure)을 침해했을 때 는 시력 상실이나 복시 등의 시각장애를 초래하는 임상적으로 
중대한 질환이 될 수 있다. 접형동 단독 병변에서 시신경이 가장 영향을 많이 받고 그 다음으로는 보고자에 따라 동안신경이
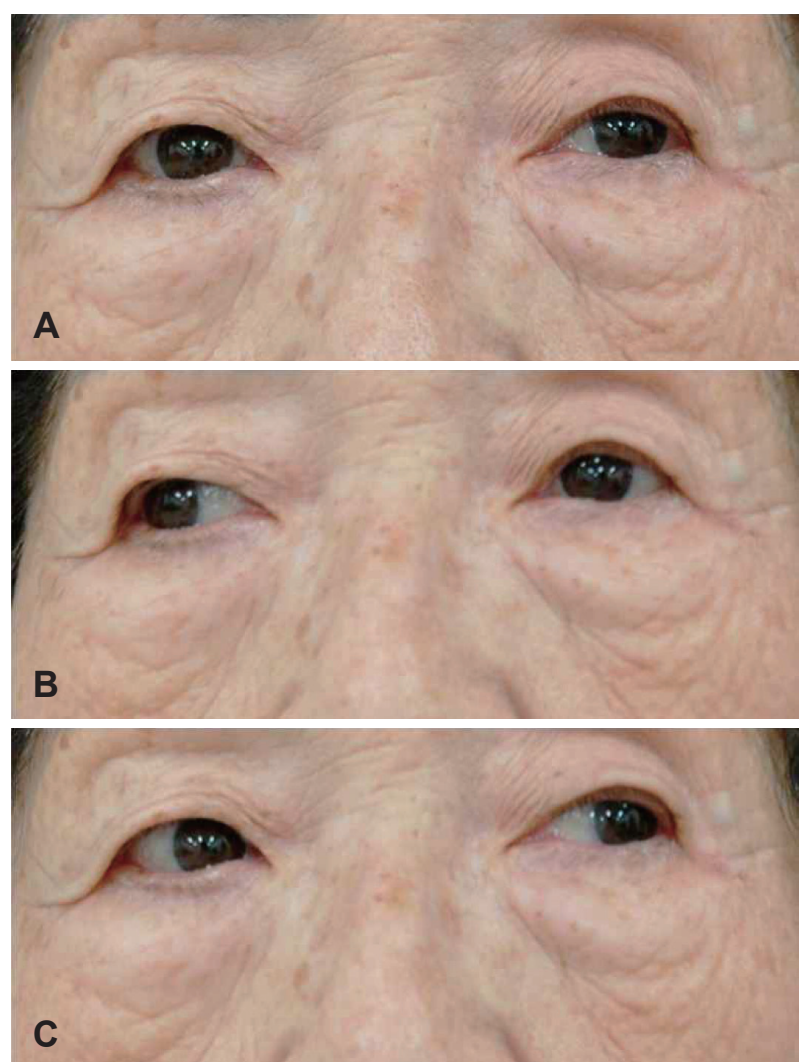

Fig. 1. Left trochlear nerve palsy in the patient with left sphenoid sinus mucocele. In primary gaze, mild incomitant hypertropia and excycloduction of the left eye are findings compatible with left superior oblique palsy (A). In right gaze, hypertropia and loss of intorsion is observed on the left eye (B). In left gaze, normal conjugate eye movement is demonstrated $(\mathrm{C})$.
나 외전신경이라고 알려져 있다. ${ }^{6,7)}$ 그러나 활차신경마비는 매 우 드물어 사골동과 접형동 점액낭종에서 시신경병(optic neuropathy)과 동반된 1예가 보고되었을 뿐이다. ${ }^{8)}$ 국내에서도 접형동 점액낭종에 의한 시신경병과 동안신경 및 외전신경 단독 마비는 각각 보고되었으나 ${ }^{9-11)}$ 활차신경 단독 마비는 아 직까지 보고된 예가 없다. 저자들은 최근 접형동 점액낭종에 의한 활차신경 단독 마비를 접형동 수술로 치료한 경험을 활 차신경의 해부학적 고찰과 함께 보고하고자 한다.

\section{증 례}

76세 여자 환자가 2일 전 발생한 좌측 두통과 복시로 응급 실에 왔다. 2주 전부터 좌측 측두두정 부위에 시각통증등급 6 7점가량의 압박성, 박동성 통증이 간헐적으로 반복되었고 강도는 점점 심해지는 양상이었다. 2일 전부터는 수직 복시가 발생하여 병원에 왔고 환자는 한쪽 눈을 가렸을 때 복시가 사라졌으며 단안시에서는 시력 저하를 느끼지 않는다고 말 하였다. 고혈압으로 약을 복용 중이고 25년 전 머리 외상으 로 후두부에 인공두개골 삽입술을 받은 병력이 있었다. 사시 검사에서 안구는 제 1 안위에서 경도의 좌측 상사시(hypertropia)를 보였고 수직 편위도가 좌측 상사근의 작용방향인 우하방 주시, 즉 좌안 내회선(intorsion) 때에 커져 좌측 상사 근마비로 판별되었다(Fig. 1). 시력을 포함한 다른 신경학적 검사에서는 이상 소견을 보이지 않았다. 따라서 환자는 상사 근을 지배하는 활차신경 단독 마비로 진단되어 원인 질환을 감별하기 위한 뇌영상검사를 시행하였다. 조영 증강 뇌 CT 및 $\mathrm{MRI}$ 축영상에서 양측 접형동을 채우고 있는 $4.0 \times 3.1 \mathrm{~cm}$
Fig. 2. Mucocele of left sphenoid sinus in axial contrast-enhanced CT scans (A and $C)$ and T2-weighted MRI (B and D). CT scans demonstrate nonenhancing opacification of both sphenoid sinuses, which is T2 hyperintense in the MRI. The heterogeneous intensity in the MRI may be related with the mucin concentration of the mucocele. The orbital apex (arrows) and clivus (arrowheads) are involved with bony erosion.
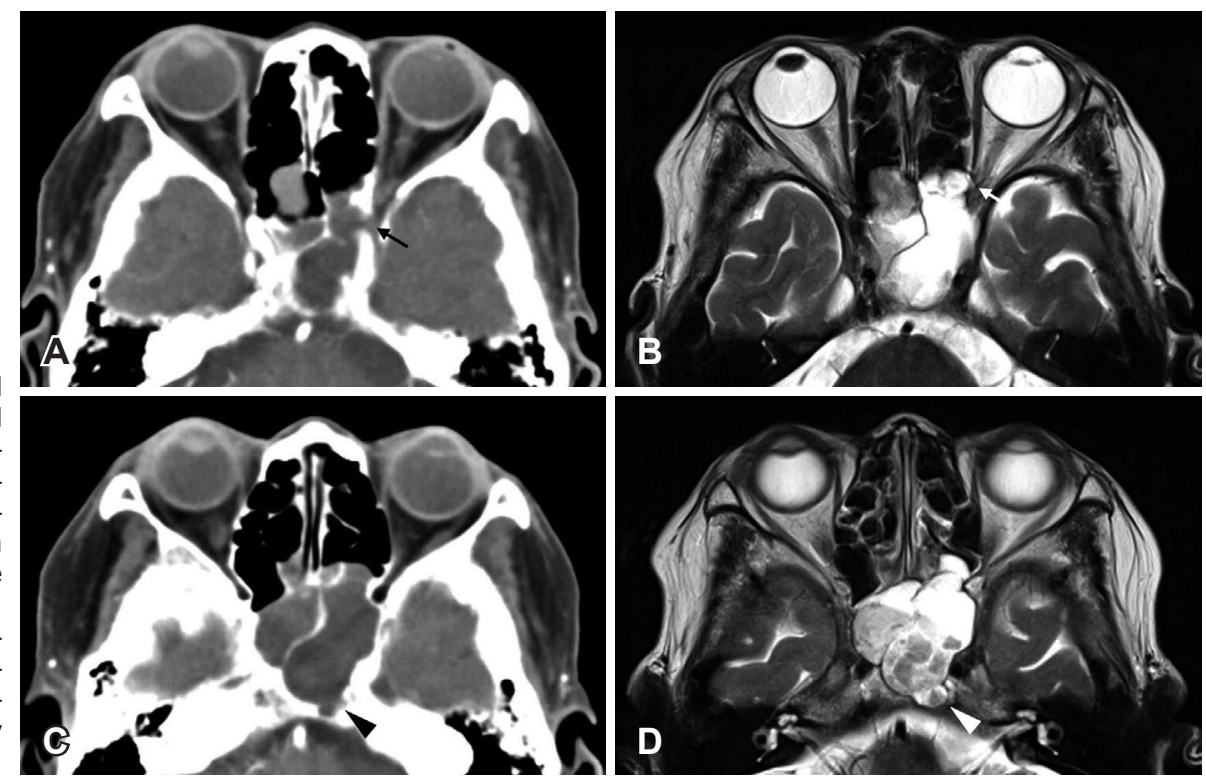

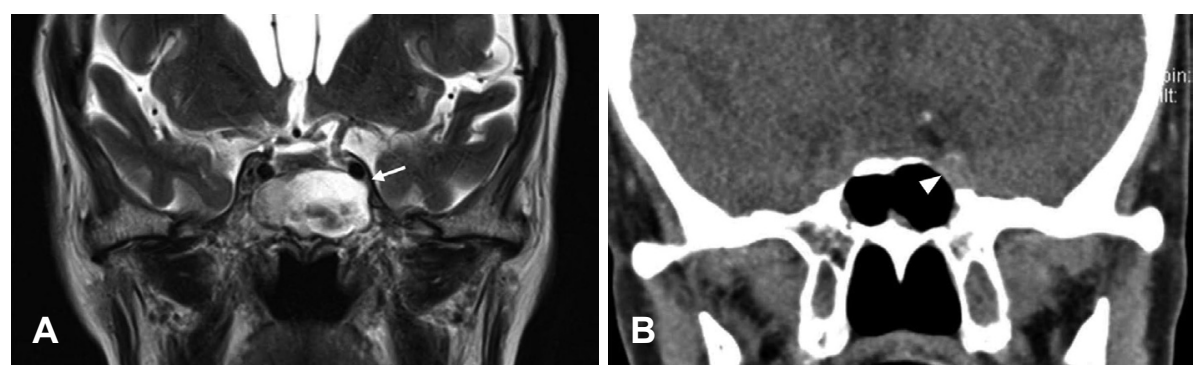

Fig. 3. Coronal images of preoperative brain MRI (A) and postoperative paranasal sinus $C T$ scan (B) at 4 months. Left cavernous sinus is compressed by the expanding mucocele (arrow). Erosion of the lateral wall of left sphenoid sinus is evident (arrowhead).

의 점액낭종에 합당한 소견이 확인되었고 좌측 안와첨(orbital apex)과 경사대(clivus)의 침범이 의심되는 소견을 보였다(Fig. 2). MRI 관상영상에서는 해면정맥동의 압축이 관찰되었다 (Fig. 3A). 비내시경검사에서 비강 내 이상 소견은 관찰되지 않 았다. 복시 발생 4일째 전신마취하에서 내시경 비강 내 접형 동절개술을 시행하였다(Kim YH). 우측 접형동에서는 고름 이 배농되었고 좌측 접형동에서는 단순 점액을 지닌 점액낭 종이 확인되었다. 낭종벽을 제거하고 배액 후 부비동을 세척 하였으며 접형동 내로 중요 구조물들의 노출은 보이지 않았 다. 양측 접형동 자연공을 전하방으로 넓게 열어 주고 양측 접형동 사이 중격을 제거한 후 합병증 없이 수술을 마쳤다. 세균배양검사에서 포도상구균이 동정되었고 입원기간 동안 항생제로 cefotetan disodium( $2 \mathrm{~g} / \mathrm{day})$ 을 사용하였으며 전신 스테로이드는 투여하지 않았다. 환자는 수술 직후 두통은 호 전되었고 복시 증상은 남아 있었으나 이것도 점차 호전되어 수술 2개월째에 완전히 소실되었고 육안으로 보아 상사근마 비도 관찰되지 않았다. 수술 4 개월째에 시행한 부비동 CT에 서 좌측 접형동 후벽의 점막 비후 이외에 연조직 음영은 관찰 되지 않았고(Fig. $3 \mathrm{~B}$ ) 환자도 특별히 호소하는 증상 없이 현재 까지 추적 관찰 중이다.

\section{고 찰}

부비동 점액낭종의 발병기전은 명확하게 밝혀져 있지 않지 만 자연공의 만성 폐쇄로 인해 점액 배출 장애가 발생되고 이 로 인해 점점 커지는 낭종을 형성한다고 알려져 있다. ${ }^{12)}$ 접형 동 질환의 가장 흔한 발현 증상은 두통으로 33 81\%의 발병 률을 보이고 두개안면부 어느 부위에서나 나타날 수 있다. 두 번째로 흔한 발현 증상은 시각장애로 단독 접형동 질환의 24 50\%에서 나타난다고 보고되었다. ${ }^{13)}$ 점액낭종이 시각장 애를 유발하는 기전은 인접한 염증에 의한 신경염, 팽창하는 병변의 압력에 의한 허혈, 그리고 혈전정맥염/혈관염에 의한 경색으로 설명할 수 있다. ${ }^{7)}$ 4번 뇌신경인 활차신경은 뇌신경 중에서 두개 내 경로가 가장 길고 두께가 가장 얇고 작은 신 경이다. ${ }^{14)}$ 활차신경핵은 하구(inferior colliculus) 위치의 중

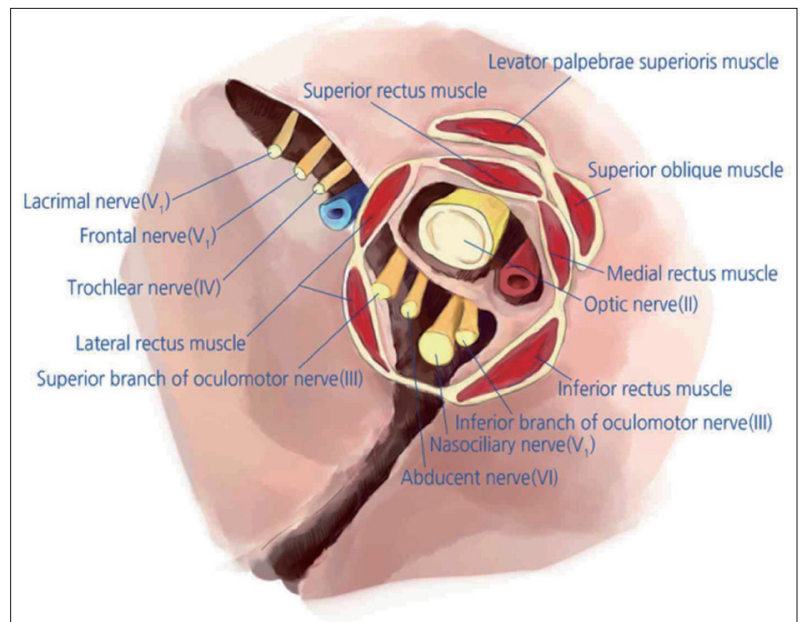

Fig. 4. Schematic drawing of the superior orbital fissure with its components at the right orbital apex. The trochlear nerve emerges in the lateral part of the superior orbital fissure, just lateral to the annulus of Zinn from which the four rectus muscles origin. The course of the trochlear nerve outside the muscle cone may contribute to its vulnerability to injuries.

심선 근처 복측 회백질에 위치해 있는데 활차신경은 배측 중 뇌에서 단일 뿌리로 시작되어 하구의 하단 외측으로 나온다. 신경은 상소뇌각 외측을 지나 교뇌 바로 위 대뇌각을 감돌아 소뇌천막(tentorium cerebelli) 밑에서 주행한 후 추체침대 주름(petroclinoid fold) 아래에서 경사대 측면을 따라 경막 을 관통하여 해면정맥동의 외측벽을 딿고 안으로 들어가 천 장 아래 측벽에서 동안신경 아래에 놓여 정맥동을 통과한다. 상안와열(superior orbital fissure)은 외직근에 의해 상외측 부와 하내측부로 나뉘는데 활차신경은 상외측부를 통해 안 구 내로 진입하여 안와지방 내에서 내측 대각선 방향으로 돌 아 상사근에 도달한다. ${ }^{2,14}$

본 환자에서 활차신경 단독 마비가 일어난 기전은 접형동 외벽의 침식으로 인한 낭종의 해면정맥동 압박보다는 안와 첨(orbital apex)에서 활차신경의 해부학적 위치와 관계가 있 을 것으로 추정된다. 활차신경은 해면정맥동 내에서 측벽의 위쪽 가장자리 동안신경의 $1 \mathrm{~mm}$ 아래에 위치하기 때문에 ${ }^{14)}$ 접형동 병변이 해면정맥동으로 침범했다면 다발성 뇌신경마 비와 동반되었을 것이다. 안와 내에서 활차신경은 뇌신경 3 , 
4, 6 번 중 유일하게 네개의 직근이 기원하는 총건륜(annulus of Zinn, common annular tendon) 바깥쪽에 위치하여 주 행한다(Fig. 4). ${ }^{14)}$ 이러한 특징적 경로가 신경 손상에 대한 취 약성에 기여할 것으로 생각되는데, CT와 MRI에서 보이는 골 침식으로 점액낭종이 안와첨을 침범하였다면 총건륜 밖에 노출되어 있는 활차신경에 염증이 침습하여 단독 마비가 올 수 있다고 생각된다. 접형동 점액낭종의 치료는 수술적으로 낭종 을 제거하고 점액 배출이 용이하도록 접형동의 전하벽을 넓 게 열어주는 것인데 최근 내시경 부비동 수술의 발달로 고식 적인 외비접근법은 대부분 내시경 수술로 대체되었다. ${ }^{15)} \mathrm{Lee}$ 등근 시각장애를 보이는 접형동 단독 질환 환자들에서 시 력 저하는 내시경 수술 후에도 비가역적인 경우가 많으나 복 시는 높은 호전율을 보인다고 하였으므로 본 증례와 같은 복 시 환자에서 신속한 진단과 수술의 중요성이 강조된다.

저자들은 복시와 두통을 호소하는 환자에서 활차신경 단 독 마비와 그 원인이 된 접형동 점액낭종을 진단하고 비강내 접형동절개술로 이를 치료하였기에 발병 기전의 해부학적 고 찰과 함께 보고한다.

\section{Acknowledgments}

We thank Bora Crystal Seo for the medical illustration.

\section{REFERENCES}

1) Berlit P. Isolated and combined pareses of cranial nerves III, IV and VI. A retrospective study of 412 patients. J Neurol Sci 1991;103 (1):10-5.

2) Mollan SP, Edwards JH, Price A, Abbott J, Burdon MA. Aetiology and outcomes of adult superior oblique palsies: a modern series.
Eye (Lond) 2009;23(3):640-4.

3) Brazis PW. Isolated palsies of cranial nerves III, IV, and VI. Semin Neurol 2009;29(1):14-28.

4) Giovannetti F, Filiaci F, Ramieri V, Ungari C. Isolated sphenoid sinus mucocele: etiology and management. J Craniofac Surg 2008;19(5): $1381-4$.

5) Siu J, Sharma S, Sowerby L. Unilateral isolated sphenoid sinusitis with contralateral abducens nerve palsy - a rare complication treated in a low-resource setting. J Otolaryngol Head Neck Surg 2015;44:9.

6) Friedmann G, Harrison S. Mucocoele of the sphenoidal sinus as a cause of recurrent oculomotor nerve palsy. J Neurol Neurosurg Psychiatry 1970;33(2):172-9.

7) Lee LA, Huang CC, Lee TJ. Prolonged visual disturbance secondary to isolated sphenoid sinus disease. Laryngoscope 2004;114(6):98690.

8) Kimakura M, Oishi A, Miyamoto K, Yoshimura N. Sphenoethmoidal mucocele masquerading as trochlear palsy. J AAPOS 2009;13(6): 598-9.

9) Jeong KS, Moon SH. A case of optic neuropathy caused by sphenoid sinus mucocele. Korean J Otolaryngol-Head Neck Surg 2004;47(11): 1195-7.

10) Lee JC, Park SK, Jang DK, Han YM. Isolated sphenoid sinus mucocele presenting as third nerve palsy. J Korean Neurosurg Soc 2010;48(4):360-2.

11) Jeon EJ, Park JY, Yoo HJ, Kim DH. A case of isolated abducens nerve palsy caused by primary sphenoid sinus mucocele. Korean J Otorhinolaryngol-Head Neck Surg 2010;53(12):781-3.

12) Delfini R, Missori P, Iannetti G, Ciappetta $P$, Cantore G. Mucoceles of the paranasal sinuses with intracranial and intraorbital extension: report of 28 cases. Neurosurgery 1993;32(6):901-6; discussion 906.

13) Nour YA, Al-Madani A, El-Daly A, Gaafar A. Isolated sphenoid sinus pathology: spectrum of diagnostic and treatment modalities. Auris Nasus Larynx 2008;35(4):500-8.

14) Joo W, Rhoton AL Jr. Microsurgical anatomy of the trochlear nerve. Clin Anat 2015;28(7):857-64.

15) Bahgat M, Bahgat $Y$, Bahgat A. Sphenoid sinus mucocele. BMJ Case Rep 2012. http://dx.doi.org/10.1136/bcr-2012-007130. 